\title{
Pensions, consumption and health: evidence from rural South Africa
}

\author{
Peter Lloyd-Sherlock ${ }^{1 *}$, Sutapa Agrawal ${ }^{2}$ and Francesc Xavier Gómez-Olivé ${ }^{3}$
}

\begin{abstract}
Background: Increasing numbers of older people in sub-Saharan Africa are gaining access to pension benefits and it is often claimed that these benefits promote healthy forms of consumption, which contribute to significant improvements in their health status. However, evidence to support these claims is limited.

Methods: The paper uses data for 2701 people aged 60 or over who participated in a population-based study in rural north-eastern South Africa. It analyses effects of receiving a pension on reported food scarcity, body mass index and patterns of consumption.

Results: The paper finds that living in a pension household is associated with a reduced risk of reported food scarcity and with higher levels of consumption of food and drink. The paper does not find that living in a pension household is associated with a higher prevalence of current smoking nor current alcohol consumption. However, the paper still finds that tobacco and alcohol make up over $40 \%$ of reported food and drink consumption, and that the correlation between reported food scarcity and body mass index status is imperfect.

Conclusions: The paper does not show significant associations between pension receipt and the selected risk factors. However, the context of prevalent obesity and high shares of household spending allocated to tobacco and alcohol call into question widely-made claims that pensions enhance healthy consumption among older people in low and middle-income countries.
\end{abstract}

Keywords: Cash transfers; older adults, Consumption, South Africa

\section{Background}

With reference to sub-Saharan Africa, there is a broad agreement across academic studies and the grey literature that receiving a pension is associated with higher rates of consumption by older people, and it is inferred that this, in turn, is associated with enhanced health and subjective wellbeing [1-6]. Similar claims are made by studies set in other low and middle-income countries, including Peru, Mexico and China [7-9]. Although the evidence supporting this received wisdom is not always robust, there is considerable plausibility to these assertions, especially in settings or for specific groups where

\footnotetext{
* Correspondence: p.lloyd-sherlock@uea.ac.uk

${ }^{1}$ School of International Development, University of East Anglia, Norwich NR4 $7 \mathrm{QE}$, UK

Full list of author information is available at the end of the article
}

income is scarce and food insecurity prevalent. As well as food, additional forms of "healthy" consumption may include medication and personal hygiene products. These arguments have played an important role in persuading governments across the region to extend or to implement new pension schemes for older people. For example, in 2018 the Kenyan government upgraded a limited set of pilot interventions into a universal old age pension scheme, while Uganda set up a new Senior Citizens Grant in 2011.

An underlying assumption of these studies is that increased consumption does not substantially include unhealthy forms of consumption. However, few publications examine the composition of consumption, with the exception of one study in Lesotho, which reports that a significant share was devoted to alcohol, tobacco and unhealthy

(c) The Author(s). 2020 Open Access This article is licensed under a Creative Commons Attribution 4.0 International License, which permits use, sharing, adaptation, distribution and reproduction in any medium or format, as long as you give appropriate credit to the original author(s) and the source, provide a link to the Creative Commons licence, and indicate if changes were made. The images or other third party material in this article are included in the article's Creative Commons licence, unless indicated otherwise in a credit line to the material. If material is not included in the article's Creative Commons licence and your intended use is not permitted by statutory regulation or exceeds the permitted use, you will need to obtain permission directly from the copyright holder. To view a copy of this licence, visit http://creativecommons.org/licenses/by/4.0/ The Creative Commons Public Domain Dedication waiver (http://creativecommons.org/publicdomain/zero/1.0/) applies to the data made available in this article, unless otherwise stated in a credit line to the data. 
foodstuffs [10]. More generally, the context of consumption and food scarcity in sub-Saharan Africa is changing rapidly. Notwithstanding substantial pockets of extreme food insecurity, the region as a whole is experiencing a rapid nutritional transition [11]. For example, the prevalence of adult overweight and obesity in urban areas of Cameroon rose from 54 to $83 \%$ between 1994 and 2003 [12]. Studies in Ghana and Kenya report that older age is a significant predictor of obesity [13, 14]. Rising rates of overweight/obesity are associated with a rapid increase in the prevalence of NCDs in sub-Saharan Africa, as are growing alcohol and tobacco consumption [15].

In the light of these trends, the persisting narrative that pensions increase consumption and that this in turn enhances the health of older people requires a more rigorous assessment. This paper provides a detailed analysis of the effects of receiving an old age pension on household consumption in rural South Africa. The paper applies a combination of bivariate and multivariate analyses to assess associations between household pension status and a range of outcomes, including self-reported food scarcity, body mass index (BMI) and specific categories of consumption. The analysis is applied to 2015 data from the Health and Aging in Africa: a Longitudinal Study of an INDEPTH Community in South Africa (HAALSI) cohort collected from Agincourt, South Africa.

\section{Methods}

The HAALSI study is a population-based survey that aims to examine and characterize a population of older men and women in rural South Africa with respect to health, well-being, and physical and cognitive function, as well as the social, environmental, and biological factors affecting these domains [16]. Participants were sampled from the existing framework of the Agincourt Health and Socio-Demographic Surveillance System (HDSS) site in Mpumalanga province [17]. The Agincourt HDSS, a rural setting in north eastern South Africa, is overseen by the MRC/Wits Agincourt Research Unit (www.agincourt.co.za). Agincourt is a former "Bantustan" area: territory set aside for the black population during the Apartheid era. Typical of such areas, basic health and education facilities and living standards are poor compared to urban and rural non-Bantustan parts of the country.

Individuals 40 years and older as on July 1, 2014 and permanently living in the study site during the 12 months previous to 2013 census round were found eligible for this study. Using the full 2013 Census data, HAALSI identified a sampling frame of 8974 women and 3901 men aged 40 years and older who met the residence criteria. The target sample size was approximately 5000 for the completed interviews. Assuming an 80\% response rate, a total of 6281 women and men were selected for the main household study.

All sampled individuals were visited at home from November 2014 to November 2015. Trained, local fieldworkers collected survey data electronically using Computer Assisted Personal Interviews. Surveys were conducted in the local Shangaan language, with instruments translated from English and back-translated to ensure reliability. Out of the 6281 selected for the study, 391 had moved outside of the study site or were deceased. Out of the remaining 5890 eligible individuals, 5059 (86\%) participated in the baseline survey. Overall, the HAALSI interviewees were slightly older than those in the Agincourt HDSS sample frame, and the gender balance was fairly skewed in the Agincourt HDSS sample frame compared to the HAALSI sample or the interviewees (as men were oversampled to obtain gender balance). The data and questionnaires for HAALSI are publically available at http://haalsi.org/.

\section{Measures}

The main exposure variable was membership of pension and non-pension households. Covariates and explanatory variables included age groups $(60-69,70-79,80+)$, sex, household wealth (lowest Q1 to highest Q5), education (no formal education, some primary (1-7 years of education), some secondary (8-11 years of education), secondary or more (12+ years of education), food scarcity in the last one year (never, sometimes/often), body mass index $\left(\mathrm{kg} / \mathrm{m}^{2}\right)$ (underweight, normal weight, overweight, obese), ever smoked (no, yes), ever drink (no, yes). We have used the standard BMI categories developed by the World Health Organization and the National Heart, Lung, and Blood Institute [18, 19]. These categories are underweight (less than 18.5), normal weight (18.5-24.9), overweight (25.0-29.9), and obese (30.0 or above). The consumption categories include staple food, meat, fruit and vegetables, milk and eggs, spices and oils, beverages and other non-alcoholic drinks such as coffee, tea, juice, water and soft drinks and tobacco and alcoholic beverages (including, beer, wine, spirits).

\section{Data analysis}

All analyses were conducted using STATA statistical software package Version 14 (College Station, Texas). Standard descriptive statistics were calculated for all variables, including means and standard deviations. Bivariate analysis was conducted and differences in categorical variables were tested using $\mathrm{X}^{2}$ tests. Further, multivariable logistic regression analysis estimated the odds ratios of household pension status on food scarcity, body mass index, current smoking or drinking status adjusted for age and sex of the household members. 


\section{Results}

Table 1 presents selected characteristics of the study population, comparing older people living in "pension households" (where at least one member reported receipt of an old age pension) and "non-pension households" (where no members reported receipt of an old age pension). For the total population aged 60 and over, $78.2 \%$ lived in pension households. There were significant bivariate associations between pension household membership and female sex, as well as primary

Table 1 Sample distribution of households with at least one elderly aged 60+ years receiving no pension and receiving pension, HAALSI 2015

\begin{tabular}{|c|c|c|c|c|}
\hline Characteristics & $\begin{array}{l}\text { Sample } \\
\text { distribution } \\
n=2701 \\
\end{array}$ & $\begin{array}{l}\text { Non-Pension } \\
\text { households } n= \\
574\end{array}$ & $\begin{array}{l}\begin{array}{l}\text { Pension } \\
\text { households } \\
n=2127\end{array} \\
\end{array}$ & $\begin{array}{l}\text { Chi sq } \\
p \text {-value }\end{array}$ \\
\hline Age groups & & & & 0.037 \\
\hline $60-69 y$ & 1274 & 49.3 & 46.6 & \\
\hline 70-79y & 802 & 25.4 & 30.8 & \\
\hline $80+y$ & 625 & 25.3 & 22.6 & \\
\hline Sex & & & & $<0.0001$ \\
\hline Male & 1283 & 55.8 & 45.3 & \\
\hline Female & 1418 & 44.3 & 54.7 & \\
\hline Household wealth & & & & 0.070 \\
\hline Q1(lowest) & 553 & 23.7 & 19.6 & \\
\hline Q2 & 545 & 16.7 & 21.1 & \\
\hline Q3 & 539 & 19.0 & 20.2 & \\
\hline Q4 & 550 & 20.7 & 20.3 & \\
\hline Q5(highest) & 514 & 19.9 & 18.8 & \\
\hline Education & & & & $<0.0001$ \\
\hline No formal education & 1600 & 64.5 & 58.2 & \\
\hline Some primary (1-7) & 860 & 25.4 & 33.8 & \\
\hline Some secondary (8-11) & 131 & 3.9 & 5.2 & \\
\hline Secondary or more $(12+)$ & 98 & 6.3 & 2.9 & \\
\hline $\begin{array}{l}\text { In the past } 1 \text { year how often did you or any household members go to sleep at night } \\
\text { hungry because there was not enough food? }\end{array}$ & & & & 0.003 \\
\hline Never & 2087 & 82.8 & 89.4 & \\
\hline Sometimes/often & 265 & 17.2 & 10.6 & \\
\hline $\begin{array}{l}\text { In the past } 1 \text { year how often did you or any household members go a whole day } \\
\text { without eating anything because there was not enough food? }\end{array}$ & & & & 0.001 \\
\hline Never & 2105 & 83.3 & 90.2 & \\
\hline Sometimes/often & 247 & 16.7 & 9.8 & \\
\hline Body Mass Index & & & & 0.022 \\
\hline Underweight & 146 & 5.9 & 5.3 & \\
\hline Normal weight & 929 & 36.9 & 33.7 & \\
\hline Overweight & 707 & 26.1 & 26.2 & \\
\hline Obese & 668 & 19.9 & 26.1 & \\
\hline Empty/missing & 251 & 11.2 & 8.8 & \\
\hline Currently smoke & & & & 0.086 \\
\hline yes & 185 & 38.7 & 30.4 & \\
\hline No & 2515 & 61.3 & 69.6 & \\
\hline Currently drink & & & & 0.277 \\
\hline Yes & 663 & 52.5 & 48.9 & \\
\hline No & 2037 & 47.5 & 51.1 & \\
\hline
\end{tabular}


education. Table 1 shows that only a minority of older people reported going to sleep hungry ( $17.2 \%$ in nonpension households; $10.6 \%$ in pension households). The prevalence of obesity/overweight was considerably higher than underweight, especially for older people in pension households (52.3\% versus 5.3\%). For the total sample, $24.5 \%$ reported that they sometimes consumed alcohol and $6.8 \%$ that they used tobacco: there were no significant bivariate associations for pension household membership.

Table 2 presents associations between two selfreported items on reported food scarcity and age, sex and pension status. The only significant results are for pension household membership, which is negatively associated with both food scarcity items. Table 3 presents bivariate associations between the same two self-report items on food scarcity and measured BMI. It shows that self-reported food scarcity is associated with lower BMI, although it is noteworthy that over $8.0 \%$ of older people measured as obese reported experiencing food scarcity and that $79.8 \%$ of those who were underweight did not.

Table 4 presents a multivariate analysis of associations between BMI categories, age, pension household category and sex. This is done in two ways: first, obesity it treated as a single category; then it is combined with overweight. In both models there is a strong positive association with female sex, but not with pension household membership. For both, there are negative associations with older age categories.

Table 5 presents bivariate analysis of levels of consumption on different items of food and drink. Tobacco and alcohol accounted for $42.7 \%$ and $42.3 \%$ of total food and drink consumption in non-pension and pension households respectively. By contrast, the corresponding figures for fruit and vegetables were 3.1 and $4.1 \%$.

Table 6 presents a multivariate analysis of selfreported current smoking and alcohol consumption by age, pension household category and sex. The analysis was conducted separately for both sexes and then for older men and women separately. No positive associations were found for household pension status. For both sexes combined, being aged 70 and over was associated with a lower probability of smoking, compared to being aged 60-69, and being aged 80 and over was associated with a lower probability of smoking, compared to being aged 60-69. The same associations were reported for older men alone. Analysis of older women was limited by the small number of observations. For both sexes

Table 2 Multivariate analysis of reported food scarcity

\begin{tabular}{|c|c|c|c|c|}
\hline & $\begin{array}{l}\text { In the past } 1 \text { year how often did you or any household } \\
\text { members go to sleep at night hungry because there was not } \\
\text { enough food? (0-never; } 1 \text {-sometimes) }\end{array}$ & $\begin{array}{l}P \\
\text { value }\end{array}$ & $\begin{array}{l}\text { In the past } 1 \text { year how often did you or any } \\
\text { household members go a whole day without } \\
\text { eating anything because there was not } \\
\text { enough food? ( } 0 \text {-never; } 1 \text {-sometimes) }\end{array}$ & $\begin{array}{l}P \\
\text { value }\end{array}$ \\
\hline & Adjusted OR[95\%Cl] & & Adjusted OR[95\%Cl] & \\
\hline \multicolumn{5}{|c|}{ Household pension status } \\
\hline $\begin{array}{l}\text { Not receive } \\
\text { pension }\end{array}$ & 1.00 & & 1.00 & \\
\hline $\begin{array}{l}\text { Receive } \\
\text { pension }\end{array}$ & $0.56[0.39-0.82]$ & 0.002 & $0.53[0.37-0.78]$ & 0.001 \\
\hline \multicolumn{5}{|l|}{ Sex } \\
\hline Male & 1.00 & & 1.00 & \\
\hline Female & $0.84[0.65-1.09]$ & 0.181 & $0.82[0.64-1.09]$ & 0.175 \\
\hline \multicolumn{5}{|l|}{ Age groups } \\
\hline $60-69 y$ & 1.00 & & 1.00 & \\
\hline 70-79y & $1.11[0.82-1.51]$ & 0.486 & $1.11[0.81-1.53]$ & 0.504 \\
\hline $80+y$ & $1.28[0.93-1.77]$ & 0.136 & $1.32[0.96-1.86]$ & 0.106 \\
\hline \multicolumn{5}{|c|}{ Number of individuals living in the household } \\
\hline Living alone & 1.00 & & 1.00 & \\
\hline $\begin{array}{l}\text { Living with } \\
\text { one other }\end{array}$ & $1.26[0.77-2.06]$ & 0.351 & $1.12[0.68-1.84]$ & 0.657 \\
\hline $\begin{array}{l}\text { Living in 3- } \\
6 \text { person }\end{array}$ & $0.97[0.65-1.46]$ & 0.894 & $0.86[0.57-1.30]$ & 0.478 \\
\hline $\begin{array}{l}\text { Living in 7+ } \\
\text { person } \\
\text { household }\end{array}$ & $1.13[0.74-1.73]$ & 0.583 & $0.99[0.64-1.52]$ & 0.949 \\
\hline
\end{tabular}


Table 3 Bivariate associations between reported food scarcity and measured BMI

\begin{tabular}{|c|c|c|c|c|}
\hline \multirow[b]{2}{*}{ Total } & \multicolumn{2}{|c|}{$\begin{array}{l}\text { In the past } 1 \text { year how often did you or any household } \\
\text { members go to sleep at night hungry because there was } \\
\text { not enough food? }\end{array}$} & \multicolumn{2}{|c|}{$\begin{array}{l}\text { In the past } 1 \text { year how often did you or any household } \\
\text { members go a whole day without eating anything because } \\
\text { there was not enough food? }\end{array}$} \\
\hline & Never $\%$ & Sometimes \% & Never \% & Sometimes \% \\
\hline Obese & 91.3 & 8.7 & 91.6 & 8.4 \\
\hline Overweight & 92.1 & 7.9 & 92.3 & 7.7 \\
\hline Normal & 85.3 & 14.8 & 87.1 & 12.9 \\
\hline Underweight & 79.8 & 20.2 & 79.8 & 20.2 \\
\hline Missing & 90.0 & 10.0 & 90.0 & 10.0 \\
\hline Chi sa $p$ value & $<0.0001$ & & $<0.0001$ & \\
\hline \multicolumn{5}{|l|}{ Men } \\
\hline Obese & 88.5 & 11.5 & 90.5 & 9.6 \\
\hline Overweight & 92.6 & 7.5 & 92.6 & 7.5 \\
\hline Normal & 85.6 & 14.4 & 86.7 & 13.3 \\
\hline Underweight & 79.3 & 20.7 & 79.3 & 20.7 \\
\hline Missing & 90.1 & 9.9 & 90.1 & 9.9 \\
\hline Chi sa $p$ value & 0.007 & & 0.008 & \\
\hline \multicolumn{5}{|l|}{ Women } \\
\hline Obese & 92.2 & 7.8 & 92.0 & 8.0 \\
\hline Overweight & 91.8 & 8.2 & 92.1 & 7.9 \\
\hline Normal & 84.8 & 15.3 & 87.7 & 12.3 \\
\hline Underweight & 81.0 & 19.1 & 81.0 & 19.1 \\
\hline Missing & 89.9 & 10.1 & 89.9 & 10.1 \\
\hline Chi sq $p$ value & 0.002 & & 0.049 & \\
\hline
\end{tabular}

combined, there were strong positive associations between male sex and current drinking, but not for current smoking.

Table 7 shows that only a very small minority of older people had received advice from health professionals about smoking, diet or losing weight. The denominator includes all older people, not just those report that currently smoke or drink, or who are overweight/obese, since it is possible that some may have modified their health risk behaviours as a result of past advice. Despite this, the numbers who report receiving advice are too small to support multivariate analysis.

\section{Discussion}

This study has a number of important limitations. First, it does not refers to a nationally representative population of older adults, and is situated in a specific setting. Second, the total sample size is modest: this both impedes the generation of statistically significant results (as for older women who smoke) and limits the generalisability of the findings. The relatively small number of non-pension households (574) reduces the capacity to study this exposure. Finally, some of the covariates, such as food scarcity, expenditure, smoking and alcohol consumption are based on self-report, and may therefore be affected by reporting biases.

Some of our findings are compatible with claims made in the wider literature. For example, our finding that pension household membership was associated with lower rates of reported food insecurity and higher rates of food and drink consumption matches the findings of quantitative and qualitative studies set in South Africa, Swaziland, Zambia, Tanzania, Ethiopia, Mexico and Peru [1-8]. However, other aspects of the research findings call into question the plausibility of claims that pensions were associated with forms of consumption that are conducive to enhanced health status. Food insecurity was rare, regardless of pension household membership, and the prevalence of obese/overweight was considerably higher than underweight. This matches the findings of other surveys which report a rapid fall in food insecurity in South Africa, as well as with general regional trends, notwithstanding the persistence of significant pockets of extreme food insecurity for some vulnerable groups and settings [11, 20, 21].

Although the bivariate association between BMI categories and reported food scarcity is significant, the correlation is not as strong as might have been expected. There are no other published studies on this relationship 
Table 4 Multivariate analysis of BMl category, age, pension household category and sex

\begin{tabular}{ll}
\hline & $\begin{array}{l}\text { Body Mass Index 0-non-obese } \\
\text { (underweight/normal/overweight) } \\
\text { 1-obese (obese) }\end{array}$ \\
& Adjusted OR[95\%Cl] \\
\hline $\begin{array}{l}\text { Household pension status } \\
\text { Not receive }\end{array}$ & 1.00 \\
pension & \\
Receive pension & $1.18[0.93-1.50]$ \\
Sex & \\
Male & 1.00 \\
Female & $3.55[2.91-4.32]$ \\
Age groups & 1.00 \\
60-69y & $0.81[0.65-1.00]$ \\
70-79y & $0.43[0.32-0.56]$ \\
$80+y$ & Body Mass Index 0-non-obese \\
(underweight/normal) 1-obese (overweight/obese)
\end{tabular}

for older people, although a study of adolescents in Tanzania found a strong association between reported food insecurity and low BMI [22]. We found that the large majority of underweight older people did not report food scarcity. This may be because low BMI can be a consequence of HIV/AIDS or TB, both of which are prevalent among older adults in the study site [23, 24]. Alternatively, this may reflect under-reporting of food scarcity due to stigma, although this effect has not been observed in other studies. Conversely, over $8 \%$ of older people who were obese self-reported food scarcity. This matches findings reported associations between reported food insecurity and obesity in the USA [25].

The prevalence of self-reported current smoking in the study population $(6.8 \%)$ is low compared to those reported by other studies. For example, a national SAGE 2 survey of South Africans aged 50 and over found that 15.5\% were current smokers [26]. Low prevalence may reflect specific aspects of the study sample, including a rural setting and relatively low levels of wealth and education compared to national populations. The reduced risk of smoking at older ages has not been reported in other studies. A survey of African townships reported that being aged 50 and over was associated with higher daily smoking, but does not make age comparisons within the older population [27].

The prevalence of current alcohol consumption (24.5\%) was considerably higher than for smoking. It is higher than rates reported by the SAGE 1 survey of South Africans aged 50 and over (15.6\%) [28], but lower than rates of regular alcohol consumption reported by a survey of adults in North West Province (mean age 49; $64 \%$ of men; $33 \%$ of women) [29].

There is no evidence that that living in a pension household was positively associated with current smoking or alcohol consumption by older people. These effects have not been assessed by other studies. However,

Table 5 Bivariate analysis of reported household consumption of food and drink

\begin{tabular}{|c|c|c|c|c|c|c|}
\hline \multirow[t]{2}{*}{$\begin{array}{l}\text { In the last } 30 \text { days, how much (mean value in Rand) } \\
\text { did permanent household member spend and consume on: }\end{array}$} & \multicolumn{2}{|l|}{$\begin{array}{l}\text { Non-Pension } \\
\text { households } n=574\end{array}$} & \multicolumn{2}{|c|}{$\begin{array}{l}\text { Pension households } n= \\
2127\end{array}$} & \multicolumn{2}{|l|}{ Total } \\
\hline & mean $[95 \% \mathrm{Cl}]$ & $\%$ & mean $[95 \% \mathrm{Cl}]$ & $\%$ & mean $[95 \% \mathrm{Cl}]$ & $\%$ \\
\hline Staple food & $360.0[266.3-453.8]$ & 13.9 & $318.5[296.0-341.1]$ & 14.0 & $322.6[300.3-344.8]$ & 13.95 \\
\hline Meat & $380.8[346.4-415.1]$ & 14.7 & $414.2[394.9-433.5]$ & 18.2 & $410.9[393.2-428.7]$ & 16.45 \\
\hline Fruits and vegetables & $80.1[70.2-90.0]$ & 3.1 & $93.0[74.4-111.7]$ & 4.1 & 91.9[74.9-108.9] & 3.6 \\
\hline Milk and eggs & $242.7[55.2-430.8]$ & 9.4 & 144.1[111.3-177.0] & 6.3 & $153.1[118.7-187.5]$ & 7.85 \\
\hline Spices and oils & $268.2[111.1-425.4]$ & 10.3 & 183.7[151.1-216.3] & 8.1 & 192.3[158.9-225.6] & 9.2 \\
\hline $\begin{array}{l}\text { Beverages and other non-alcoholic } \\
\text { drinks such as coffee, tea, juice, water } \\
\text { and soft drinks }\end{array}$ & $154.5[52.6-256.4]$ & 6.0 & $160.1[127.6-192.6]$ & 7.0 & 159.6[128.6-190.5] & 6.5 \\
\hline $\begin{array}{l}\text { Tobacco and alcoholic beverages } \\
\text { (including, beer, wine, spirits) }\end{array}$ & 1106.7[339.3-1874.1] & 42.7 & $962.8[717.6-1207.9]$ & 42.3 & $978.1[744.5-1211.6]$ & 42.5 \\
\hline TOTAL & 2592.7 & & 2276.4 & & 2434.6 & \\
\hline
\end{tabular}


Table 6 Multivariate analysis of self-reported smoking (current) and alcohol consumption (current) by age, pension household category and sex

\begin{tabular}{|c|c|c|c|c|}
\hline \multicolumn{5}{|l|}{ Both sexes } \\
\hline & Currently Smoke 0-no 1- Yes & $P$ value & Currently drink 0-no 1- Yes & $P$ value \\
\hline & Adjusted OR[95\%Cl] & & Adjusted OR[95\%Cl] & \\
\hline \multicolumn{5}{|l|}{ Household pension status } \\
\hline Not receive pension & 1.00 & & 1.00 & \\
\hline Receive pension & $0.72[0.47-1.11]$ & 0.139 & $0.87[0.67-1.14]$ & 0.318 \\
\hline \multicolumn{5}{|l|}{ Sex } \\
\hline Male & 1.00 & & 1.00 & \\
\hline Female & $0.53[0.21-1.35]$ & 0.185 & $0.50[0.40-0.64]$ & $<0.0001$ \\
\hline \multicolumn{5}{|l|}{ Age groups } \\
\hline $60-69 y$ & 1.00 & & 1.00 & \\
\hline 70-79y & $0.40[0.26-0.61]$ & $<0.0001$ & $0.89[0.69-1.15]$ & 0.374 \\
\hline $80+y$ & $0.43[0.26-0.74]$ & 0.002 & $0.65[0.49-0.86]$ & 0.002 \\
\hline \multicolumn{5}{|l|}{ Men } \\
\hline \multicolumn{5}{|c|}{ Household pension status } \\
\hline Not receive pension & 1.00 & & 1.00 & \\
\hline Receive pension & $0.83[0.53-1.29]$ & 0.400 & $0.91[0.66-1.25]$ & 0.563 \\
\hline \multicolumn{5}{|l|}{ Age groups } \\
\hline $60-69 y$ & 1.00 & & 1.00 & \\
\hline 70-79y & $0.38[0.25-0.59]$ & $<0.0001$ & $0.86[0.64-1.16]$ & 0.324 \\
\hline $80+y$ & $0.40[0.23-0.69]$ & 0.001 & $0.64[0.44-0.92]$ & 0.015 \\
\hline \multicolumn{5}{|l|}{ Women } \\
\hline & $\begin{array}{l}\text { Currently Smoke* } \\
0 \text {-no } \\
1-\text { Yes }\end{array}$ & $P$ value & $\begin{array}{l}\text { Currently drink } \\
0 \text {-no } \\
1-\text { Yes }\end{array}$ & $P$ value \\
\hline & Adjusted OR[95\%Cl] & & Adjusted OR[95\%Cl] & \\
\hline \multicolumn{5}{|l|}{ Household pension status } \\
\hline Not receive pension & 1.00 & & 1.00 & \\
\hline Receive pension & - & & $0.80[0.50-1.28]$ & 0.356 \\
\hline \multicolumn{5}{|l|}{ Age groups } \\
\hline $60-69 y$ & 1.00 & & 1.00 & \\
\hline 70-79y & - & & $0.97[0.60-1.57]$ & 0.906 \\
\hline $80+y$ & - & & $0.66[0.41-1.07]$ & 0.090 \\
\hline
\end{tabular}

${ }^{*} \mathrm{MV}$ analysis cannot be run due to small no of cases

Table 7 Advice received from health professionals

\begin{tabular}{|c|c|c|c|c|}
\hline & $\begin{array}{l}\text { Sample distribution } \% \\
{[n=2701]}\end{array}$ & $\begin{array}{l}\text { Non-Pension } \\
\text { households } n=574\end{array}$ & $\begin{array}{l}\text { Pension households } \\
n=2127\end{array}$ & $\begin{array}{l}\text { Chi sq } p \text { - } \\
\text { value }\end{array}$ \\
\hline $\begin{array}{l}\text { Has a doctor, nurse or other healthcare worker ever } \\
\text { advised you to stop smoking? }\end{array}$ & 19.1 [110] & $15.1[18]$ & 20.1 [92] & 0.284 \\
\hline $\begin{array}{l}\text { Has a doctor nurse or other health care worker ever told } \\
\text { you to change your diet? }\end{array}$ & $12.3[331]$ & $10.5[60]$ & 12.7 [271] & 0.251 \\
\hline $\begin{array}{l}\text { Has a doctor nurse or other health care worker ever } \\
\text { advised you to lose weight? }\end{array}$ & $2.9[78]$ & $2.6[15]$ & 3.0 [63] & 0.796 \\
\hline
\end{tabular}


across all households considerably larger shares of household food and drink consumption were allocated to tobacco and alcohol than to fruit and vegetables. This is in keeping with data on high rates of tobacco and alcohol consumption in countries like South Africa, although studies specifically related to their share of household spending are not available [30]. It is unclear what share of household spending on tobacco and alcohol was due to consumption by older people or by younger family members. There is evidence from other studies that pension income is often shared with other household members, both willingly and coercively [31].

The small numbers of older people who received advice from health professionals about diet, smoking or weight loss are striking given the high levels of reported unhealthy consumption and the prevalence of overweight/obesity in the study population. Similar analysis has not been published elsewhere. The case for health advice is reinforced by the findings of nationally surveys of populations aged 50 and over in South Africa and Ghana in 2014/15 [32]. These show that a substantially larger share of the South African sample (62.4\%) reported consuming insufficient fruit and vegetables than did the Ghana sample (48.5\%). The same survey found $79.8 \%$ of the South African sample reported engaging in insufficient physical activity, compared to $39.4 \%$ of the Ghanaian one. These findings are of particular interest, since, compared to South Africa, rates of overweight and obesity are lower in Ghana, health service availability is more limited and, in the absence of extensive pension coverage, average incomes of older people are considerably lower.

Taken together, the findings of this study indicate claims that providing older people with pensions will promote healthier patterns of consumption are increasingly questionable in sub-Saharan African settings. These claims are based on a view of the region which became out-dated as the nutritional transition commenced. Arguably, this nutritional transition is further advanced in South Africa than in less affluent countries in the region. However, data from other studies show a rapid pace of change across the region [11]. Moreover, this study is situated in a relatively poor rural setting, where it is to be expected that effects associated with nutritional transition would be less evident than for the country as a whole. Few other studies examine the potential effects of pensions or other cash transfers on unhealthy consumption. One exceptional study examines the effects of a targeted cash transfer for mothers in Mexico and finds an association with excess calorie consumption [33].

There is a large body of evidence demonstrating that obesity and unhealthy consumption are leading risk factors for ill-health and disability for older people in sub-
Saharan Africa [34-36]. The current focus of policy for older people in the region is heavily geared to the provision of pensions and income security [37, 38]. At the same time, older people are explicitly marginalised from the emerging global NCD agenda [39]. There is an urgent need to take a more inter-sectoral approach, including targeted public health interventions to improve awareness about nutrition and health behaviours among older people. Currently, there are almost no examples of such interventions in the region, a notable exception being a pilot project that screened older people for hypertension and provided low-sodium salt at pension paypoints [40]. The positive initial evaluation of this project points the way towards developing interventions that combine health and income security. New social pension schemes are being set up across sub-Saharan Africa. Rather than make assertions about pensions and consumption that are founded on increasingly outdated views of local context, there may be opportunities to directly link pension provision to health interventions. If this is done, then pensions may indeed provide a platform for healthy consumption and behaviours among the region's rapidly growing older population.

\section{Conclusion}

This study calls into question general claims about the effects of social pensions on consumption and health in low and middle-income countries. Specifically, it shows that increased consumption of food and drink associated with pension receipt does not necessarily lead to improvements in health status. There may have been links between increased consumption and enhanced health status in rural South Africa in the past when earlier studies were conducted, but these settings have experienced rapid nutritional transition and have seen sharp increases in the prevalence of obesity. Evidence from other parts of sub-Saharan Africa indicates that these changes are broadly typical of the region as a whole, albeit more advanced. As such, it cannot be assumed that providing older people with social pensions is an effective stand-alone intervention for enhancing their health.

The study also indicates a need for primary health care services to adapt to new challenges related to population ageing and non-communicable disease. At its simplest, this could take the form of more systematic provision of advice about diet, smoking and alcohol consumption. More ambitiously, there may be scope to bundle specific health promotion interventions into pension distribution systems. To date, however, there is little indication that such interventions are being developed in South Africa.

\section{Abbreviations}

BMI: Body Mass Index; HAALSI: Health and Aging in Africa: a Longitudinal Study of an INDEPTH Community in South Africa; HDSS: Health and SocioDemographic Surveillance System; NCD: Non-Communicable Disease 


\section{Acknowledgements}

Not applicable.

\section{Authors' contributions}

PLS led the analytical and conceptual design and the drafting of the paper. SA led the data analysis. FGO supported the analytical design and redrafting of the paper. All authors have read and approved the manuscript.

\section{Funding}

The data collection for this work was supported by the National Institute on Aging at the National Institute of Health (1P01AG041710-01A1) HAAL SI-Health and Aging in Africa: Longitudinal Studies of INDEPTH Communities.

The data analysis was funded by a UK Economic and Social Research Council grant, Interventions for older people in sub-Saharan Africa (ES/P003516/1). The Agincourt HDSS was supported by the Wellcome Trust, UK (058893/Z/ 99/A; 069683/Z/02/Z; 085477/Z/08/Z; and 085477/B/08/Z), the University of the Witwatersrand and South African Medical Research Council.

\section{Availability of data and materials}

The datasets generated and/or analysed during the current study are available at the Harvard Center for Population and Development Studies (HCPDS) program website: www.haalsi.org.

\section{Ethics approval and consent to participate}

The study received ethical approvals from the University of the Witwatersrand Human Research Ethics Committee (ref M141159), the Harvard T.H. Chan School of Public Health, Office of Human Research Administration (ref C13-1608-02), and the Mpumalanga Provincial Research and Ethics Committee (approved: 2014/10/22). Each respondent provided written, informed consent (or by a proxy, when needed).

\section{Consent for publication}

Not applicable.

\section{Competing interests}

No financial or non-financial competing interests.

\section{Author details}

${ }^{1}$ School of International Development, University of East Anglia, Norwich NR4 7QE, UK. ${ }^{2}$ Public Health Foundation of India, New Delhi, India. ${ }^{3} \mathrm{MRC}$ Wits Rural Public Health and Health Transitions Research Unit (Agincourt), School of Public Health, University of the Witwatersrand, South Africa. Harvard Center for Population and Development Studies, Harvard University, Harvard, USA.

Received: 27 December 2019 Accepted: 8 October 2020

Published online: 20 October 2020

\section{References}

1. Case A. Does money protect health status? Evidence from South African pensions". NBER Working Paper 8495, National Bureau of Economic Research, Cambridge, M.A. 2001.

2. Regional Hunger and Vulnerability Programme (RHVP) and HelpAge International Swaziland old age grant impact assessment (2010) https://www.eldis.org/document/A62172.

3. HelpAge International) A social pension in Zambia. Perceptions of the cash transfer pilot in Katete (2009 http://www.helpage.org/download/4f059863 de502/ [accessed 1.8.18]

4. Hofmann S, Heslop M, Clacherty G and Kessy F salt, soap and shoes for school. The impact of pensions on the lives of older people and grandchildren in the KwaWazee project in Tanzania's Kagera region (2008) http://www.eldis.org/document/A41059 [accessed 1.8.18].

5. Stefanoni S, Lloyd-Sherlock P, Bukuluki P, Williamson C, Wandiembe SP and Van Eys T Social protection and access to health services in Ethiopia, Mozambique, Tanzania and Zimbabwe. 2017. http://www.helpage.es/silo/ files/cash-transfers--.pdf. Accessed 1 Aug 2018.

6. Chane Y, Hailu G, Kumera G. Pension beneficiaries' household food insecurity and associated factors in Debre Markos town, Northwest Ethiopia. BMC Res Notes. 2018;11(1):561.
7. Cavero-Arguedas D, Cruzado de la Vega V, Cuadra-Carrasco G. Los efectos de los programas sociales en la salud de la población en condición de pobreza: Evidencias a partir de las evaluaciones de impacto del presupuesto por resultados a programas sociales en Perú. Rev Peruana Med Exp Salud Pública. 2017;34(3):528-37.

8. Franco-Alvarez N, Avila-Funes JA, Ruiz-Arreguí L, Gutiérrez-Robledo LM. Determinantes del riesgo de desnutrición en los adultos mayores de la comunidad: análisis secundario del estudio Salud, Bienestar y Envejecimiento (SABE) en México. Rev Panam Salud Publica. 2007;22(6):369-75.

9. Huamao Z, Teng $Z$. The impacts of social pension on rural household expenditure: evidence from China. J Econ Policy Reform. 2016;19(3):221-37.

10. Ranotsi A, Aiyuk S. Impact of the pension on access to health and selected food stuffs for pensioners of the Manonyane Community in Roma, Lesotho as measured between 2004 and 2006. Healthy Aging Clin Care Elderly. 2012:4:27-31.

11. Steyn N, McHiza Z. Obesity and the nutrition transition in sub-Saharan Africa. Ann N Y Acad Sci. 2014;1311:88-101.

12. Echouffo-Tcheugui J, Kengne A. Chronic non-communicable diseases in Cameroon -burden, determinants and current policies. Glob Health. 2011;7:44.

13. Mbochi R, Kuria E, Kimiywe J, et al. Predictors of overweight and obesity in adult women in Nairobi Province, Kenya. BMC Public Health. 2012;12:823.

14. Dake F, Tawiah E, Badasu D. Sociodemographic correlates of obesity among Ghanaian women. Public Health Nutr. 2010;14:1285.

15. Mensah G, Mayosi B. The 2011 United Nations high-level meeting on noncommunicable diseases: the Africa agenda calls for a 5-by-5 approach. S Afr Med J. 2012:103(2):77-9.

16. Gómez-Olivé, F, Montana, L, Wagner R, et al. Cohort Profile: Health and Aging in Africa: A Longitudinal Study of an INDEPTH Community in South Africa (HAALSI). International Journal of Epidemiology, 2018 (forthcoming)

17. Kahn K, Collinson M, Gómez-Olivé F, et al. Profile: Agincourt health and socio-demographic surveillance system. Int J Epidemiol. 2012;41:988-1001.

18. Obesity: preventing and managing the global epidemic. Report of a WHO consultation. World Health Org Technical Rep Series 2000; 894:i-xii. 1-253.

19. Clinical guidelines on the identification, evaluation, and treatment of overweight and obesity in adults: executive summary. Expert Panel on the Identification, Evaluation, and Treatment of Overweight in Adults. Am J Clin Nutr. 1998;68(4):899-917.

20. Labadarios D, McHiza Z, Steyn N, et al. Food security in South Africa: a review of national surveys. Bull World Health Org. 2011:89(12):891-9.

21. Kimani-Murage E, Schofield L, Wekesah F, et al. Vulnerability to food insecurity in urban slums: experiences from Nairobi, Kenya. J Urban Health. 2014;91(6):1098-113.

22. Cordeiro L, Wilde P, Semu H, Levinson F. Household food security is inversely associated with undernutrition among adolescents from Kilosa, Tanzania. J Nutr. 2012;142(9):1741-7.

23. Villamor E, Saathoff E, Mugusi F, et al. Wasting and body composition of adults with pulmonary tuberculosis in relation to HIV-1 coinfection, socioeconomic status, and severity of tuberculosis. Eur J Clin Nutr. 2006;60(2):163-71.

24. Mojola S, Williams J, Angotti N, Gómez-Olivé F. HIV after 40 in rural South Africa: a life course approach to HIV vulnerability among middle aged and older adults. Soc Sci Med. 2015;143:204-12.

25. Dinour $L$, Bergen $D$, Yeh $M$. The food insecurity-obesity paradox: a review of the literature and the role food stamps may play. J Am Diet Assoc. 2007; 107(11):1952-61.

26. Ware LJ, Charlton K, Kruger R, Breet Y, van Rooyen J, et al. Assessing tobacco use in an African population: serum and urine cotinine cut-offs from South Africa. Drug Alcohol Depend. 2019;195:82-9.

27. Peltzer K, Chao L, Ramlagan S, Szrek H. Daily tobacco use and problem drinking among urban adults in South Africa: a longitudinal study. Pan Afr Med J. 2019:32:51.

28. Martinez P, Lien L, Landheim A, Kowal P, Clausen T. Quality of life and social engagement of alcohol abstainers and users among older adults in South Africa. BMC Public Health. 2014;14:316.

29. Pisa P, Vorster H, Kruger A, Margetts B, Loots du T. Association of alcohol consumption with specific biomarkers: a cross-sectional study in South Africa. J Health Popul Nutr. 2015;33(1):146-56.

30. van Heerden A, Barnabas R, Norris S, et al. High prevalence of HIV and noncommunicable disease (NCD) risk factors in rural KwaZulu-Natal, South Africa. J Int AIDS Soc. 2017;20:e25012.

31. Lloyd-Sherlock P, Ayiga N, Penhale B. Financial abuse of older people in low and middle-income countries: the case of South Africa. J Elder Abuse Neglect. 2018;30(3):236-46. 
32. He, W, Kowal, $\mathrm{P}$ and Naidoo, N. Trends in health and wellbeing of the older population in SAGE countries: 2014-2015. United States Census Bureau and World Health Organisation 2018. https://www.census.gov/content/dam/ Census/library/publications/2018/demo/p95-18-01.pdf.

33. Leroy J, Gadsden P, Rodríguez-Ramírez S, de Cossío T. Cash and in-kind transfers in poor rural communities in Mexico increase household fruit, vegetable, and micronutrient consumption but also lead to excess energy consumption. J Nutr. 2010;140(3):612-7.

34. Lloyd-Sherlock P, Minicuci N, Beard J, et al. Hypertension among older adults in low and middle income countries: prevalence, awareness and control. Int J Epidemiol. 2014;14(1):116-28.

35. Peltzer K, Phaswana-Mafuya N. Problem drinking and associated factors in older adults in South Africa. Afr J Psychiatr. 2013;16(2):104-9.

36. Negin J, Cumming R, de Ramirez S, Abimbola S, Sachs S. Risk factors for non-communicable diseases among older adults in rural Africa. Trop Med Int Health. 2011;16(5):640-6.

37. HelpAge International. Achieving income security in old age: Taking stock and pushing the boundaries. 2012. https://www.humanitarianlibrary.org/resource/ achieving-income-security-older-age-taking-stock-and-pushing-boundaries. Accessed 1 Aug 2018.

38. Kakwani $\mathrm{N}$ and Subbarao K. Ageing and poverty in Africa and the role of social pensions. World Bank 2005 https://openknowledge.worldbank.org/ handle/10986/8535 [accessed 1.8.18].

39. Lloyd-Sherlock P, Ebrahim S, McKee M, Prince M. Institutionally ageist? Global health policy in the 21st century. Br Med J. 2016;354:14514.

40. Lloyd-Sherlock P, Gomez-Olive F, Ngobeni S, Wagner R, Tollman S. Pensions and low sodium salt: a qualitative evaluation of a new strategy for managing hypertension in rural South Africa. Curr Aging Sci. 2018. https:/ doi.org/10.2174/1874609811666180718114250.

\section{Publisher's Note}

Springer Nature remains neutral with regard to jurisdictional claims in published maps and institutional affiliations.

Ready to submit your research? Choose BMC and benefit from:

- fast, convenient online submission

- thorough peer review by experienced researchers in your field

- rapid publication on acceptance

- support for research data, including large and complex data types

- gold Open Access which fosters wider collaboration and increased citations

- maximum visibility for your research: over $100 \mathrm{M}$ website views per year

At $\mathrm{BMC}$, research is always in progress.

Learn more biomedcentral.com/submissions 